\section{Case Reports in Neurology}

Case Rep Neurol 2020;12:314-320

DOI: $10.1159 / 000509684$

Published online: September 18, 2020

(C) 2020 The Author(s)

Published by S. Karger AG, Basel

www.karger.com/crn

This article is licensed under the Creative Commons Attribution-NonCommercial 4.0 International License (CC BY-NC) (http://www.karger.com/Services/OpenAccessLicense). Usage and distribution for commercial purposes requires written permission.

\title{
A Case of Cervical Spondylotic Amyotrophy Mimicking Amyotrophic Lateral Sclerosis
}

\author{
Pretty Sara Idiculla Raghav Govindarajan \\ University of Missouri Health Care, Columbia, MO, USA
}

\section{Keywords}

Cervical spondylotic amyotrophy · Cervical spondylosis · Differentials of cervical spondylotic amyotrophy

\begin{abstract}
Cervical spondylotic amyotrophy (CSA) is a rare clinical condition characterized by weakness and atrophy of the upper limb with minimal to no associated sensory deficits. The detection of the disease is based on clinical features at presentation, neurological examination, electrophysiological studies, and imaging. The proposed pathophysiological mechanisms include selective damage to the ventral root or anterior horn cells of the spinal cord. Depending on the muscle groups that are involved, CSA is broadly classified into a proximal type and a distal type. The clinical profiles of patients with CSA and ALS have a very close resemblance to each other, especially at the early stages of the disease. Cervical spine magnetic resonance imaging (MRI) may show T2 hyperintensity in both proximal and distal types. Electromyogram demonstrates denervation potentials and reduced motor unit potentials in the affected muscles. The conservative management is often the first-line modality, and those who fail to respond to conservative treatment have severe muscular atrophy and weakness, and distal-type CSA are considered potential candidates for surgery. We present the case of a 57-year-old female who presented with a 1-year history of left-hand weakness and wasting with no sensory deficits.
\end{abstract}




\section{Case Reports in Neurology}

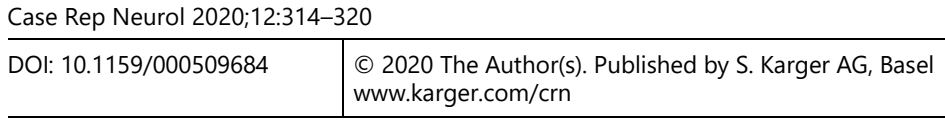

Idiculla and Govindarajan: A Case of Cervical Spondylotic Amyotrophy Mimicking Amyotrophic Lateral Sclerosis

She denied any involvement of her other hand or bilateral lower limbs, and she was referred to our clinic with the potential diagnosis of amyotrophic lateral sclerosis (ALS). An elaborate history, physical examination, electrophysiological studies, and imaging assisted us in reaching the diagnosis of CSA, 1 year after the onset of symptoms.

(C) 2020 The Author(s)

Published by S. Karger AG, Basel

\section{Introduction}

Cervical spondylotic amyotrophy (CSA) is a rare condition associated with cervical spondylosis where there is severe muscular weakness and wasting of the upper limb muscles with no sensory involvement. The precise incidence of CSA is yet to be established and various pathophysiological mechanisms have been postulated by multiple studies. Diagnosis requires a comprehensive neurological examination, imaging and electrophysiological studies, which help exclude other differentials that may have a similar presentation. CSA is treatable with good prognosis, though treatment still remains controversial.

\section{Case Presentation}

A 57-year-old right-handed female, with no significant past medical conditions presented with a 1-year history of progressively worsening weakness and reducing function of her left hand. This was associated with muscle wasting, which she noticed when she felt increasing difficulty to grip on objects resulting in frequent dropping of things from her hand. She eventually developed weakness to even lift up her fingers. She had denied any similar complaints in her other hand as well as bilateral lower limbs. She indicates that she has occasional neck pain since the last 1 year. However, she denied any history of cervical or head trauma, imbalance, falls, no right-sided or lower extremity symptoms, and bladder or bowel difficulties. She was referred to us for further evaluation as her treating physicians were concerned about amyotrophic lateral sclerosis (ALS).

On examination, left upper extremity strength was $5 / 5$ except, hand grip was $2 / 5$, finger adduction and abduction were $2 / 5$ and dorsiflexion of the wrist and fingers were $2 / 5$. Fasciculations, mild atrophy of the forearm and atrophy of the intrinsic hand muscles as well as both thenar and hypothenar muscles (with no evidence of split hand sign). Strength was 5/5 throughout the right upper and lower extremities, and the left lower extremities. Reflexes were $3+/ 4$ in biceps, triceps, and brachioradialis bilaterally; and 3+/4 in bilateral knees and ankles. Hoffman and Babinski signs were present bilaterally. Sensory modalities such as pinprick, vibration and tactile sensation is equal and intact in both arms and legs.

Left upper extremity motor NCS (nerve conduction study) shows very mild prolonged distal motor latency ( $<120 \%$ upper limit of normal), significantly reduced median and radial nerve CMAP (compound muscle action potential) and borderline slow conduction velocity. Evoked response is absent in the left ulnar nerve. Motor nerve conduction studies of the right median, ulnar, fibular, and tibial nerves were found to have normal distal motor latency, evoked response amplitude and conduction velocity. Sensory evoked response is with normal limits in both arms but there was significant reduction of amplitude in medial and lateral 


\section{Case Reports in Neurology}

\begin{tabular}{l|l} 
Case Rep Neurol 2020;12:314-320 \\
\hline DOI: 10.1159/000509684 & $\begin{array}{l}\text { @ } 2020 \text { The Author(s). Published by S. Karger AG, Basel } \\
\text { www.karger.com/crn }\end{array}$ \\
\hline
\end{tabular}

Idiculla and Govindarajan: A Case of Cervical Spondylotic Amyotrophy Mimicking Amyotrophic Lateral Sclerosis

antebrachial cutaneous nerve on the left hand. Electromyogram (EMG) was performed which revealed an active denervation in left first dorsal interosseous, abductor pollicis brevis, flexor digitorum profundus, and extensor indicis proprius. MUAP (motor unit potentials) could not be assessed due to lack of activation in these muscles. EMG of all other muscles tested in bilateral legs and right arm show no abnormal spontaneous activity, normal duration MUAPs and full or reduced recruitment on maximal or submaximal stimulus. Electrodiagnostic studies revealed medial and lower trunk left brachial plexopathy but did not show any evidence of motor neuron disease, generalized large fiber neuropathy. Magnetic resonance imaging (MRI) of the C-spine revealed severe kyphoscoliosis with spinal canal and neuroforaminal stenosis worse at C7-T1 levels, with a diffuse T2 hyperintensity extending from C5-T1 levels, and enhancement of the anterior nerve roots (Fig. 1). MRI of the brachial plexus was found to be normal.

The patient underwent a combined anterior-posterior decompression, and instrumented fusion with cervical spine reconstruction was performed. Her post-operative recovery was uneventful. On 6-month follow-up, examination showed improvement in muscle bulk hand, muscle strength had improved to left wrist extension (4/5), hand grip (3/5), and finger abduction/abduction $(3 / 5)$.

\section{Discussion}

Cervical spondylotic amyotrophy (CSA) is a rare condition associated with cervical spondylosis where there is severe muscular weakness and wasting of the upper limb muscles with little to no sensory involvement or pyramidal signs [1]. Some studies have included the occurrence of pyramidal tract signs indicating the involvement of the lower extremities as part of their definition of CSA [2]. In most cases, it is characterized by a severe, unilateral upper limb muscular atrophy in patients aged between 50 and 60 years and is rarely bilateral, with a slightly higher male predominance [3]. Though CSA is associated with cervical spondylosis, its occurrence is not determined by the severity of degenerative changes in the spine [4].

The exact incidence of CSA is yet to be established and the etiopathogenesis has been attributed to the selective involvement of the ventral nerve roots or anterior horn cells or both. The anterior horn cells can be affected by vascular insufficiency as a result of spinal canal stenosis or vessel impingement from cervical spine movement [5]. Based on the muscle groups that are affected, CSA has been broadly classified into a proximal and a distal type. The proximal type affects the scapular muscles, deltoid, and the biceps; due to involvement at the C5C6 segments. The distal type affects the triceps, forearm muscles, and intrinsic hand muscles; from involvement at the C7-T1 segments [3]. A diffuse form has also been explained which involves atrophy of both proximal and distal muscles [6]. Occasionally, sensory disturbances in the upper extremities or hyperreflexia in the lower limbs has been found in these patients [7]. The distal type occurs in an older age group, has a lower incidence, a chronic course, affects multiple spinal segments, and the MRI detection in the form of T2 hyperintensity is high [5].

Cervical spine MRI may show T2 hyperintensity in both proximal and distal types, indicating spinal cord compression and canal stenosis [8]. MRI can help detect the presence of impingement on the anterior horn cells or ventral nerve root [9]. Standard needle EMG 


\section{Case Reports in Neurology}

\begin{tabular}{l|l} 
Case Rep Neurol 2020;12:314-320 \\
\hline DOI: 10.1159/000509684 & $\begin{array}{l}\text { @ } 2020 \text { The Author(s). Published by S. Karger AG, Basel } \\
\text { www.karger.com/crn }\end{array}$ \\
\hline
\end{tabular}

Idiculla and Govindarajan: A Case of Cervical Spondylotic Amyotrophy Mimicking Amyotrophic Lateral Sclerosis

demonstrates denervation potentials and reduced motor unit potentials in the affected muscles, confined to the upper limbs without a lower limb or paraspinal muscle involvement [10]. Electrophysiologic findings may help explain the underlying pathophysiology of the clinical presentation in CSA patients. EMG demonstrating fibrillatory and positive sharp waves indicates involvement of anterior radix or nerve root, whereas fasciculation and synchronization indicates a lower motor neuron injury of the anterior horn [3].

The common differentials of CSA include motor neuron disease (particularly ALS); Hirayama disease (juvenile muscular atrophy of the distal upper extremity); rotator cuff tears (a differential for proximal-type CSA); or Parsonage-Turner syndrome (acute brachial plexus neuropathy due to neuralgic amyotrophy of the shoulder). The diagnosis of CSA is important as they usually follow a self-limiting disease course and tend to stabilize after the initial progression of muscular atrophy and weakness [11]. The clinical profiles of patients with CSA and ALS, summarized in Table 1, have close resemblance to each other and these conditions can co-exist in the same patient, adding to the diagnostic dilemma. Hirayama disease, also called monomelic amyotrophy, can have a close resemblance to CSA and the comparative profiles have been summarized in Table 2 .

Conservative management is often the first-line modality including neck immobilization with collars, cervical traction, physical therapy, and regular follow-ups to determine disease progression. Use of vitamin B12, vitamin E, PGE1 administration, and hyperbaric oxygen therapy seems to show effectiveness but lacks sufficient substantiating evidence [12]. Patients who fail to respond to conservative treatment (no response after 4 months), have severe muscular atrophy and weakness; and have distal-type CSA, are considered potential candidates for early surgical management [13]. A recent retrospective study suggested anterior decompression as the first choice of intervention and posterior decompression as an option for patients in whom the anterior approach was difficult or impossible [7]. However, no evidence is currently available that can point to the best surgical option for the treatment of CSA. Various predictive factors have been determined to indicate the surgical outcome. Increased pre-operative muscle weakness, long duration of symptoms, older patient age, and distal-type CSA are considered predictors of poor outcomes [12]. Patients with involvement of the anterior horn cell or both anterior horn cell and ventral nerve root, also tend to have a poor surgical outcome [11].

Our patient presented to us with a 1-year history of progressively worsening weakness and reducing function of her left hand. Her MRI revealed diffuse T2-hyperintensity extending from C5-T1 levels, and EMG showed denervation involving nerve roots C7-T1 with neurogenic motor unit potentials. She was initially referred to us with the potential diagnosis of ALS due to the similar clinical presentation and a thorough clinical history, examination and substantiating EMG as well as imaging helped us to diagnose distal-type CSA. The significant hand weakness which limited activities of daily living guided us to proceed with surgery for the patient, and a 6-month follow-up showed a significant improvement in muscle strength.

\section{Conclusion}

CSA is a rare clinical entity characterized by severe muscular weakness and wasting of the upper limb muscles (either proximal or distal) without significant sensory involvement 


\section{Case Reports in Neurology}

Case Rep Neurol 2020;12:314-320
$\begin{array}{ll}\text { DOI: } 10.1159 / 000509684 & \begin{array}{l}\text { (c) 2020 The Author(s). Published by S. Karger AG, Basel } \\ \text { www.karger.com/crn }\end{array}\end{array}$

Idiculla and Govindarajan: A Case of Cervical Spondylotic Amyotrophy Mimicking Amyotrophic Lateral Sclerosis

and is commonly unilateral. Distal type CSA demonstrates a more chronic course, occurs in an older age group, has multi-segment involvement, and is associated with a poor surgical outcome. Surgery is indicated in patients who fail conservative treatment, have severe muscle weakness and atrophy, as well as in distal form of CSA. It is challenging and critical to identify and differentiate CSA from conditions with a similar clinical presentation like ALS as the former is a potentially treatable condition with a good prognosis.

\section{Statement of Ethics}

An informed, written consent was obtained from the patient to publish this case, including publication of images.

\section{Conflict of Interest Statement}

The authors declare that they have no conflicts of interests.

\section{Funding Sources}

No funding was received.

\section{Author Contributions}

All authors have been involved in the preparation of the manuscript. All authors have read and approved the manuscript. The corresponding author has full access to data and has the right to publish this data.

\section{References}

1 Funaba M, Kanchiku T, Imajo Y, Suzuki H, Yoshida Y, Nishida N, et al. A Novel Scoring System Associated With Surgical Outcome of Distal-type Cervical Spondylotic Amyotrophy. Clin Spine Surg. 2017 Nov;30(9):E1182-9.

2 Iizuka Y, Iizuka H, Mieda T, Kobayashi R, Tsutsumi S, Nakajima T, et al. Prognostic factors for cervical spondylotic amyotrophy: are signs of spinal cord involvement associated with the neurological prognosis? Spinal Cord. 2014 May;52(5):364-7.

3 Takahashi T, Hanakita J, Minami M, Tomita Y, Sasagasako T, Kanematsu R. Cervical Spondylotic Amyotrophy: Case Series and Review of the Literature. Neurospine. 2019 Sep;16(3):579-88.

4 Mori K, Yamamoto T, Nakao Y, Maeda M. Cervical spondylotic amyotrophy treated by anterior decompression. Three case reports. Neurol Med Chir (Tokyo). 2006 Jul;46(7):366-70.

5 Jiang SD, Jiang LS, Dai LY. Cervical spondylotic amyotrophy. Eur Spine J. 2011 Mar;20(3):351-7.

6 Tofuku K, Koga H, Yone K, Komiya S. Conservative treatment with hyperbaric oxygen therapy for cervical spondylotic amyotrophy. Spinal Cord. 2011 Jun;49(6):749-53.

7 Li T, Shi G, Shi L, Miao J, Chen D, Chen Y. Clinical Features and Long-Term Surgical Outcomes of Patients with Cervical Spondylotic Amyotrophy. World Neurosurg. 2019 Jan;121:e172-80. 


\section{Case Reports in Neurology}

\begin{tabular}{l|l}
\hline Case Rep Neurol 2020;12:314-320 \\
\hline DOI: 10.1159/000509684 & $\begin{array}{l}\text { (c) 2020 The Author(s). Published by S. Karger AG, Basel } \\
\text { www.karger.com/crn }\end{array}$ \\
\hline
\end{tabular}

Idiculla and Govindarajan: A Case of Cervical Spondylotic Amyotrophy Mimicking Amyotrophic Lateral Sclerosis

8 Wang HL, Li HC, Jiang JY, Lū FZ, Chen WJ, Ma XS. Evaluation of characteristics and surgical outcomes in cervical spondylotic amyotrophy. Indian J Orthop. 2014 Sep;48(5):511-7.

9 Fujiwara Y, Tanaka N, Fujimoto Y, Nakanishi K, Kamei N, Ochi M. Surgical outcome of posterior decompression for cervical spondylosis with unilateral upper extremity amyotrophy. Spine. 2006 Sep;31(20):E728-32.

10 Kaneko K, Taguchi T, Toyoda K, Kato Y, Azuma Y, Kawai S. Distal-type cervical spondylotic amyotrophy: assessment of pathophysiology from radiological findings on magnetic resonance imaging and epidurally recorded spinal cord responses. Spine. 2004 May;29(9):E185-8.

11 Uchida K, Nakajima H, Yayama T, Sato R, Kobayashi S, Kokubo Y, et al. Anterior and posterior decompressive surgery for progressive amyotrophy associated with cervical spondylosis: a retrospective study of 51 patients. J Neurosurg Spine. 2009 Sep;11(3):330-7.

12 Luo W, Li Y, Xu Q, Gu R, Zhao J. Cervical spondylotic amyotrophy: a systematic review. Eur Spine J. 2019 Oct;28(10):2293-301.

13 Tauchi, R., Imagama, S., Inoh, H., Yukawa, Y., Kanemura, T., Sato, K., et al. (2013). Risk factors for a poor outcome following surgical treatment of cervical spondylotic amyotrophy: a multicenter study. European spine journal: official publication of the European Spine Society, the European Spinal Deformity Society, and the European Section of the Cervical Spine Research Society, 22(1), 156-161. https://doi.org/10.1007/s00586-012-2506-6.

14 Tiryaki E, Horak HA. ALS and other motor neuron diseases. Continuum (Minneap Minn). 2014;20(5 Peripheral Nervous System Disorders):1185-1207. https://doi.org/10.1212/01.CON.0000455886.14298.a4.

15 Foster E, Tsang BK, Kam A, Storey E, Day B, Hill A. Hirayama disease. J Clin Neurosci. 2015 Jun;22(6):951-4.

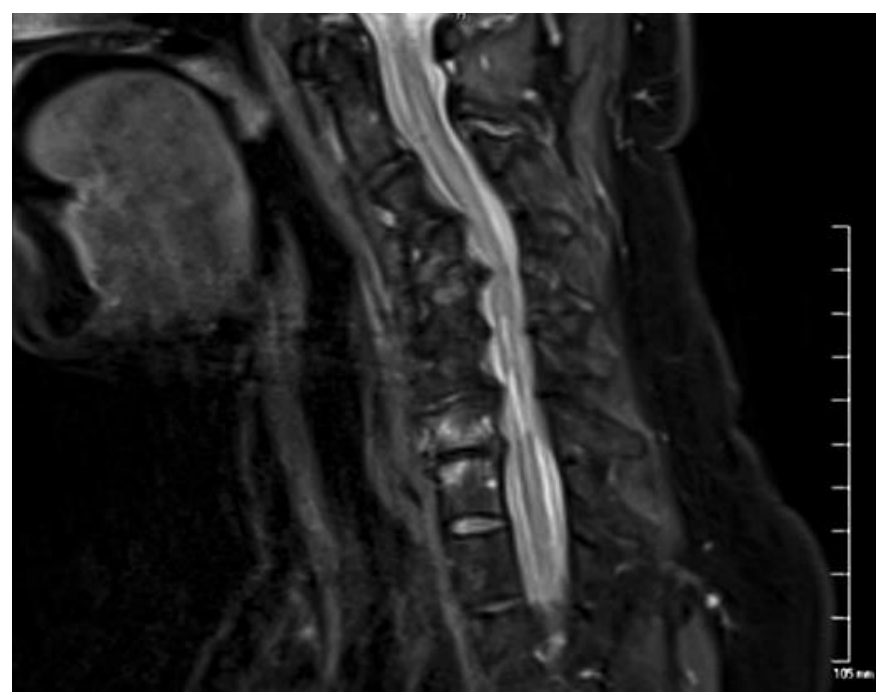

Fig. 1. MRI C spine showing multilevel spinal canal stenosis with myelomalacia. 


\section{Case Reports in Neurology}

\begin{tabular}{l|l} 
Case Rep Neurol 2020;12:314-320 \\
\hline DOI: 10.1159/000509684 & $\begin{array}{l}\text { (c) } 2020 \text { The Author(s). Published by S. Karger AG, Basel } \\
\text { www.karger.com/crn }\end{array}$ \\
\hline
\end{tabular}

Idiculla and Govindarajan: A Case of Cervical Spondylotic Amyotrophy Mimicking Amyotrophic Lateral Sclerosis

Table 1. Patient profiles associated with CSA versus ALS

\begin{tabular}{lll}
\hline Characteristics & Cervical spondylotic amyotrophy & Amyotrophic lateral sclerosis \\
\hline Age of onset & $50-60$ years [3] & 50-75 years [12] \\
\hline Pathology & $\begin{array}{l}\text { Condition associated with cervical spondylo- } \\
\text { sis [1] }\end{array}$ & $\begin{array}{l}\text { Degeneration of motor neurons in the primary motor } \\
\text { cortex; brain stem; and the spinal cord [14] }\end{array}$ \\
\hline Clinical profile & $\begin{array}{l}\text { Severe muscular weakness and wasting of } \\
\text { the upper limb muscles with little to no sen- } \\
\text { sory involvement or pyramidal signs [1] }\end{array}$ & $\begin{array}{l}\text { Progressive muscle paralysis, the presence of bulbar } \\
\text { symptoms, no sensory involvement, cognitive abnormal- } \\
\text { ities in the form of frontotemporal dysfunction, upper } \\
\text { motor neuron symptoms and signs, or spread of symp- } \\
\text { toms are hallmark signs [14] }\end{array}$ \\
\hline EMG & $\begin{array}{l}\text { Changes are detected exclusively in the atro- } \\
\text { phied muscles [5] }\end{array}$ & $\begin{array}{l}\text { There is a more diffuse involvement and it is essential to } \\
\text { determine bulbar disease by examining the tongue, fa- } \\
\text { cial muscles, trapezius and/or sternocleidomastoid [12] }\end{array}$ \\
\hline Outcome & $\begin{array}{l}\text { Self-limiting disease and tend to stabilize af- } \\
\text { ter the initial progression [12] }\end{array}$ & $\begin{array}{l}\text { Progressive fatal neurodegenerative disease [14] } \\
\end{array}$ \\
\hline
\end{tabular}

Table 2. Patient profiles associated with CSA versus Hirayama disease

\begin{tabular}{|c|c|c|}
\hline Characteristics & Cervical spondylotic amyotrophy & Hirayama disease [15] \\
\hline Age of onset & $50-60$ years $[3]$ & Adolescence and early 3rd decade \\
\hline Pathology & $\begin{array}{l}\text { Condition associated with cervical spondylo- } \\
\text { sis [1] }\end{array}$ & $\begin{array}{l}\text { Flexion-induced compression of the spinal cord at C7- } \\
\text { T1 levels }\end{array}$ \\
\hline Clinical profile & $\begin{array}{l}\text { Severe muscular weakness and wasting of the } \\
\text { upper limb muscles with little to no sensory } \\
\text { involvement or pyramidal signs [1] }\end{array}$ & $\begin{array}{l}\text { Commonly unilateral, symmetric or asymmetric mus- } \\
\text { cle weakness and atrophy at C7-T1 muscle distribu- } \\
\text { tion with relative sparing of the brachioradialis; also } \\
\text { commonly associated with cold paresis and irregular } \\
\text { tremors on finger extension; there is no sensory in- } \\
\text { volvement or pyramidal signs }\end{array}$ \\
\hline $\begin{array}{l}\text { Electrophysiological } \\
\text { studies }\end{array}$ & $\begin{array}{l}\text { EMG demonstrates denervation potentials } \\
\text { and reduced motor unit potentials in the af- } \\
\text { fected muscles [10] }\end{array}$ & $\begin{array}{l}\text { NCS show severe reduction in ulnar CMAP, and com- } \\
\text { paratively lesser reduction in median CMAP }\end{array}$ \\
\hline MRI & $\begin{array}{l}\text { Cervical spine MRI may show T2-hyperinten- } \\
\text { sity in both proximal and distal types, indicat- } \\
\text { ing spinal cord compression and canal steno- } \\
\text { sis [8] }\end{array}$ & $\begin{array}{l}\text { Typically, MRI on neck flexion shows anterior shift of } \\
\text { posterior dura with spinal cord flattening against C7- } \\
\text { T1 vertebrae, reduced posterior cervical subarachnoid } \\
\text { space, and contrast-enhancement of posterior cervical } \\
\text { epidural space }\end{array}$ \\
\hline Outcome & $\begin{array}{l}\text { Self-limiting disease and tend to stabilize after } \\
\text { the initial progression [12] }\end{array}$ & $\begin{array}{l}\text { r Benign and though initially progressive, it ultimately } \\
\text { has a non-progressive course }\end{array}$ \\
\hline
\end{tabular}

